\title{
Cyanobacteria-Mediated Arsenic Redox Dynamics Is Regulated by Phosphate in Aquatic Environments
}

\author{
Siyu Zhang, ${ }^{\dagger \neq}$ Christopher Rensing, ${ }^{\S}$ and Yong-Guan $\mathrm{Zhu}^{*, \dagger, \|}$
}

${ }^{\dagger}$ State Key Lab of Urban and Regional Ecology, Research Center for Eco-Environmental Sciences, Chinese Academy of Sciences, Beijing 100085, People's Republic of China

${ }^{\ddagger}$ University of Chinese Academy of Sciences, Beijing 100049, People’s Republic of China

${ }^{\S}$ Department of Plant and Environmental Sciences, University of Copenhagen, Thorvaldsensvej 40, DK-1871 Frederiksberg C, Denmark

"Key Laboratory of Urban Environment and Health, Institute of Urban Environment, Chinese Academy of Sciences, Xiamen, 361021 Fujian, People's Republic of China

\section{Supporting Information}

ABSTRACT: Studies of cyanobacteria in environments where arsenic (As) and phosphate (P) both occur in significant concentrations have so far only focused on the effect of $\mathrm{P}$ on As $(\mathrm{V})$ toxicity and bioaccumulation, with little attention to the influence of $\mathrm{P}$ on As redox transformations. Our study revealed that As(III) oxidation by Synechocystis appeared to be more effective with increased P levels. We demonstrated that the higher As(III) percentage in the medium under P-limited conditions was due to enhanced $\mathrm{As}(\mathrm{V})$ uptake and the subsequent efflux of intracellularly reduced As(III) which in turn contributed to higher As(III) concentrations in the medium. Arsenic redox changes by Synechocystis under P-limited conditions is a dynamic cyclic process that includes the following: surface As(III) oxidation (either in the periplasm or near the outer membrane), As(V) uptake, intracellular As(V) reduction, and As(III) efflux. These observations not only expand our understanding of how $\mathrm{P}$ influences microbial As redox metabolisms but also provide insights into the biogeochemical coupling between As and $\mathrm{P}$ in As contaminated eutrophic aquatic environments and artificial wetland-paddy fields.

\section{Dynamic As redox cycle under P limitation}

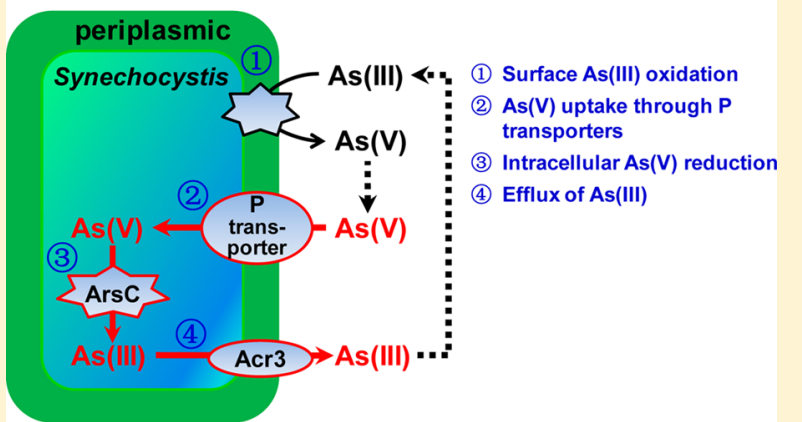

\section{INTRODUCTION}

Arsenic (As) is a ubiquitous toxic substance broadly distributed in the environment. ${ }^{1}$ The transport and transformation of As in environment are governed by geochemical and biological processes, generating an As biogeochemical cycle. ${ }^{2}$ Microbially mediated biotransformations may play an important role in determining As biogeochemistry and toxicity in various natural ecosystems, especially As redox processes which influence the two most abundant inorganic As forms (arsenite As(III) and arsenate $\mathrm{As}(\mathrm{V}))$ in the environment. ${ }^{3}$ Thus it is essential to understand microbial As redox metabolisms to make further advances in As bioremediation.

Microalgae are desirable organisms for As remediation in contaminated water because of their high surface area to volume ratios. ${ }^{4}$ Studies have shown that microalgae can tolerate high levels of As and biotransform it in several ways to detoxify it. $^{5-9}$ Considering the complex living environments of microalgae, many factors could affect As biotransformations by microalgae. Phosphate $(\mathrm{P})$ is one of the most significant determinants of microalgal growth. Due to its structural similarity with As $(\mathrm{V}),{ }^{10}$ the influence of $\mathrm{P}$ on microbial As metabolisms has been extensively studied and primarily focused on $\mathrm{As}(\mathrm{V})$ accumulation and toxicity. ${ }^{11,12}$

Besides affecting As $(\mathrm{V})$ uptake, $\mathrm{P}$ can further influence the subsequent As detoxification process, i.e. As $(\mathrm{V})$ reduction. ${ }^{13,14}$ In the bacteria Agrobacterium tumefaciens str. 5B, it has been reported that $\mathrm{As}(\mathrm{V})$ reduction was completely suppressed at elevated levels of $\mathrm{P}$ (500 and $1000 \mu \mathrm{M})$, but the expression of the $\mathrm{As}(\mathrm{V})$ reductase gene $(\operatorname{ars} \mathrm{C})$ was not inhibited by high $\mathrm{P}$ concentrations. ${ }^{15}$ As(III) oxidation and the Phosphorus (Pi) concentration were reported to be tightly and intimately coregulated in the soil bacterium Agrobacterium tumefaciens. ${ }^{16}$ However, when analyzing As(III) oxidation under different $\mathrm{P}$ levels, Slaughter et al. ${ }^{15}$ suggested that the presence of $\mathrm{P}$ had little apparent effect on As(III) oxidation in the same oxidizing strain of Agrobacterium tumefaciens. Little has been studied regarding the influence of $\mathrm{P}$ on As redox processes in

Received: August 29, 2013

Revised: November 8, 2013

Accepted: December 20, 2013

Published: December 20, 2013 
cyanobacteria or other microalgae. Even less is known about how $\mathrm{P}$ mediates the dynamics of As redox processes in cyanobacteria.

Cyanobacteria are widely distributed in the environment, ${ }^{17,18}$ and they are dominant in algal blooms, which are primarily caused by high P levels, ${ }^{19}$ especially in aquatic environments of higher trophic levels. ${ }^{20,21}$ Considering cyanobacterial blooms and As pollution coexist in many freshwater lakes in China, ${ }^{12}$ it is important to understand the effect of $\mathrm{P}$ on As transformations in cyanobacteria and therefore facilitate the application of cyanobacteria in As remediation. In this study, we chose the typical freshwater cyanobacteria Synechocystis sp. PCC6803 to study the influence of P concentrations on As redox processes. Furthermore, the genes encoding As $(\mathrm{V})$ reductase ( $\operatorname{ars} C$ slr0946) and As(III) efflux pump protein (acr3 slr0944) have been identified in Synechocystis, ${ }^{22}$ and As resistance in Synechocystis has been reported to be mediated by an operon of the three genes acr3 (slr 0944), arsH (slr0945), and $\operatorname{arsC}$ (slr0946), which is regulated by ArsR. ${ }^{22,23}$ Considering this, we used quantitative real-time polymerase chain reaction (qPCR) to analyze the expression of ars $C$ under $+\mathrm{P}$ and $-\mathrm{P}$ conditions and provide further insights on the effect of different $\mathrm{P}$ concentrations on As redox processes in Synechocystis.

\section{MATERIALS AND METHODS}

Cultivation and Growth Conditions. Synechocystis was obtained from the Institute of Hydrobiology, Chinese Academy of Sciences, Wuhan, China and grown in $100 \mathrm{~mL}$ of BG-11 medium $\left(230 \mu \mathrm{M} \mathrm{K} \mathrm{K}_{2} \mathrm{HPO}_{4}\right)^{24}$ in $250 \mathrm{~mL}$ conical flasks. Cultures were maintained in a controlled-environment growth chamber under the following conditions: $16 \mathrm{~h}$ light period day $^{-1}$ with a light intensity of approximately $280 \mathrm{mmol} \mathrm{m}^{-2} \mathrm{~s}^{-1}$, $25{ }^{\circ} \mathrm{C} / 20{ }^{\circ} \mathrm{C}$ of day/night temperatures, and $60 \%$ relative humidity. The inoculum used in the experiments came from an exponential phase culture.

Measurement of As(III) Oxidation under Different P Concentrations. Cells of Synechocystis were precultured in BG-11 medium for 7 days, then collected by centrifugation (6000 rpm), and subsequently rinsed with BG-11 medium without phosphorus addition for three times to remove $\mathrm{P}$ on the cyanobacterial surface. The collected cyanobacterial cells were then transferred to $100 \mathrm{~mL}$ medium without $\mathrm{P}$ for 3 days in order to consume all remaining phosphorus in vivo. After preculture, cells of Synechocystis were incubated at an initial optical density $\left(\mathrm{OD}_{730}\right)$ of 0.260 in a medium consisting of 10 $\mu \mathrm{M}$ As(III) $\left(\mathrm{NaAsO}_{2}\right)$ with different added concentrations of $\mathrm{P}$ $(0,10,50,75,100,150,230,690 \mu \mathrm{M})$. $\mathrm{P}$ was supplied as $\mathrm{K}_{2} \mathrm{HPO}_{4}$. To ensure the concentration of maintained $\mathrm{K}^{+}$in BG11 medium $(460 \mu \mathrm{M}), \mathrm{KCl}$ was added to each sample to ensure equal concentration of $\mathrm{K}^{+}$. For instance, $230 \mu \mathrm{M} \mathrm{K}_{2} \mathrm{HPO}_{4}$ was replaced with $460 \mu \mathrm{M} \mathrm{KCl}$ to acquire $0 \mu \mathrm{M} \mathrm{P} \mathrm{BG-11} \mathrm{medium.}$ Three replicates were measured for each treatment. After exposure for 7 days, aliquots of $2 \mathrm{~mL}$ medium were taken and filtered through $0.45 \mu \mathrm{m}$ nylon filter and kept in the freezer at $-80{ }^{\circ} \mathrm{C}$ for analysis of As speciation. The percentage of oxidized As $(\mathrm{V})$ to total As in medium was evaluated.

Short Time-Course of As Redox by Synechocystis under Different $\mathbf{P}$ and DNP Treatments. DNP (uncoupling agent 2,4-dinitrophenol) is a respiration inhibitor and an uncoupler of oxidative phosphorylation. It can cause dissipation of the proton motive force across the membranes and thus inhibits As uptake by microorganism. ${ }^{25}$ In order to locate
As(III) oxidation by Synechocystis, the effect of DNP on As redox transformations by Synechocystis under different $\mathrm{P}$ conditions was investigated. Synechocystis was exposed to 2 $\mu \mathrm{M} \operatorname{As}(\mathrm{III})\left(\mathrm{NaAsO}_{2}\right)$ or $\mathrm{As}(\mathrm{V})\left(\mathrm{Na}_{3} \mathrm{AsO}_{4}\right)$ for $48 \mathrm{~h}$ in medium with four different treatments, including - P - DNP (medium without $\mathrm{P}$ and DNP addition), $-\mathrm{P}+\mathrm{DNP}$ (medium with DNP addition, and no $\mathrm{P}$ addition), + $\mathrm{P}-\mathrm{DNP}$ (medium with $\mathrm{P}$ addition, and no DNP addition), and $+\mathrm{P}+\mathrm{DNP}$ (medium with $\mathrm{P}$ and DNP addition). DNP was supplied at 500 $\mu \mathrm{M}$, and $\mathrm{P}$ was supplied at $230 \mu \mathrm{M}$ (the normal $\mathrm{P}$ concentration in BG-11 medium). Each treatment was replicated 3 -fold. Aliquots of $2 \mathrm{~mL}$ medium were taken at 0 , $8,16,24,48 \mathrm{~h}$, filtered through a $0.45 \mu \mathrm{m}$ nylon filter and kept in the freezer at $-80{ }^{\circ} \mathrm{C}$ for later analysis. Control treatment (without cyanobacterial cells) and dead cells treatment (sterile medium after inoculation with Synechocystis) were carried out in the same way as described above. After exposure for up to $48 \mathrm{~h}$, cyanobacterial cells were collected and processed as described above. As speciation both in vivo and in the medium was determined. The percentages of As(III) and As(V) to total As in the medium were calculated respectively to evaluate the efficiency of As(III) oxidation and As(V) reduction.

Determination of As Speciation in Medium and in Cells after Exposure to As(III) under Different $P$ Concentrations. Synechocystis $(10 \mathrm{~mL}$ at the exponential growth stage) was inoculated in $90 \mathrm{~mL}$ of P modified BG-11 medium adjusted as follows: $5 \mu \mathrm{M}$ of $\mathrm{PO}_{4}{ }^{3-}$ as the P-limited condition (replaced with equal concentration of $\mathrm{K}^{+}$using $\mathrm{KCl}$ ), $230 \mu \mathrm{M}$ of $\mathrm{PO}_{4}{ }^{3-}$ as the P-rich condition. Arsenic was supplied as $\mathrm{NaAsO}_{2}$ at $10 \mu \mathrm{M}$. Three replicates were used in a completely randomized experimental design. After exposure to As(III) for $0,2,4,6,8,10$ days, aliquots of $2 \mathrm{~mL}$ of medium were taken and cyanobacteria were collected by centrifugation $(6000 \mathrm{rpm})$ and subsequent rinsing with deionized water and ice-cold $\mathrm{P}$ buffer $\left(1 \mathrm{mM} \mathrm{K} \mathrm{HPO}_{4}, 5 \mathrm{mM}\right.$ MES and $0.5 \mathrm{mM}$ $\left.\mathrm{Ca}\left(\mathrm{NO}_{3}\right)_{2}\right)$ for $10 \mathrm{~min}$ to remove apoplastic As. Cyanobacterial cells were freeze-dried and kept in $50 \mathrm{~mL}$ polypropylene tubes with $10 \mathrm{~mL}$ of $1 \% \mathrm{HNO}_{3}$ overnight. The samples were extracted using a microwave (CEM Microwave Technology Ltd., Matthews, NC, USA). The working program was as follows: $55{ }^{\circ} \mathrm{C}$ for $10 \mathrm{~min}, 75{ }^{\circ} \mathrm{C}$ for $10 \mathrm{~min}$, and $95{ }^{\circ} \mathrm{C}$ for 30 min, with 5 min ramp time between each stage. ${ }^{26}$ Supernatants from medium and cellular extractions were filtered through $0.45 \mu \mathrm{m}$ nylon filter and kept in the freezer at $-80{ }^{\circ} \mathrm{C}$ for As speciation analysis. Growth of Synechocystis at 0, 2, 4, 6, 8, 10 days was measured as optical density at $730 \mathrm{~nm}\left(\mathrm{OD}_{730}\right)$.

RNA Isolation and Quantitative Real-Time Polymerase Chain Reaction (qPCR). RNA was extracted from Synechocystis cultivated under four treatments (+ P + As(III), $+\mathrm{P}-\mathrm{As}(\mathrm{III}),-\mathrm{P}+\mathrm{As}(\mathrm{III}),-\mathrm{P}-\mathrm{As}(\mathrm{III}))$ after 7 days. Arsenite was supplied at $10 \mu \mathrm{M}$, and $\mathrm{P}$ was supplied at $230 \mu \mathrm{M}$. The cell pellet was collected and frozen in liquid nitrogen. Total RNA was isolated from Synechocystis using TRIzol reagent (Invitrogen), following the manufacturer's recommendations. DNaseI (Promega, USA) was used to remove contaminating genomic DNA. The extracted RNA was reverse transcribed using a PrimeScript RT-PCR Kit (Promega, USA) and random primers. Primers ( $\operatorname{ars} \mathrm{C}-\mathrm{F}$, $\operatorname{ars} \mathrm{C}-\mathrm{R}, r n p B-\mathrm{F}, r n p B-\mathrm{R}$ ) (Table S1) were selected to amplify a $150 \mathrm{bp}$ region inside the predicted region of transcriptional overlap of ars $C$ and $r n p B$. qPCR with SYBR Green I was performed on iQTM5 Thermocycler (Bio-Rad, USA) using SYBR Premix Ex TaqTM (Takara Bio Inc., Japan). Each qPCR was performed 
in triplicate with $r n p B$ as the internal standard. The PCR amplification profile was $95{ }^{\circ} \mathrm{C}$ for $30 \mathrm{~s}$ followed by 40 cycles of $95{ }^{\circ} \mathrm{C}$ for $5 \mathrm{~s}, 60{ }^{\circ} \mathrm{C}$ for $30 \mathrm{~s}, 72{ }^{\circ} \mathrm{C}$ for $30 \mathrm{~s}, 80^{\circ} \mathrm{C}$ for $10 \mathrm{~s}$. The relative changes in gene expression were calculated using the 2 $-[\Delta \mathrm{CP}$ sample $-\Delta \mathrm{CP}$ control $]$ formula. ${ }^{27}$

Arsenic Speciation Analysis. Arsenic speciation was determined by HPLC-ICP-MS (7500a; Agilent Technologies) as described. ${ }^{26}$ Chromatographic columns were obtained from Hamilton and consisted of a precolumn $(11.2 \mathrm{~mm}, 12-20 \mu \mathrm{m})$ and a PRP-X100 $10-\mu \mathrm{m}$ anion-exchange column $(250 \times 4.1$ $\mathrm{mm})$. The mobile phase consisted of $10 \mathrm{mM}$ diammonium hydrogenphosphate $\left(\left(\mathrm{NH}_{4}\right)_{2} \mathrm{HPO}_{4}\right)$ and $10 \mathrm{mM}$ ammonium nitrate $\left(\mathrm{NH}_{4} \mathrm{NO}_{3}\right)$, adjusted to $\mathrm{pH} 6.2$ using nitric acid. The mobile phase was pumped through the column isocratically at 1 $\mathrm{mL} \mathrm{min}^{-1}$. Arsenic species in the samples were identified by comparing their retention time with those of the standards, including arsenite $(\mathrm{As}(\mathrm{III}))$, arsenate $(\mathrm{As}(\mathrm{V}))$, and quantified by external calibration curves with peak areas.

\section{RESULTS}

As(III) Is Oxidized by Synechocystis. Fresh cells (Synechocystis), dead cells, and control treatment (without cyanobacterial cells) were prepared to investigate As(III) oxidation (Figure S1). After exposure to $2 \mu \mathrm{M}$ As(III) for 48 h, $45.0 \%$ of As(III) was oxidized to As(V) by Synechocystis, which was significantly $(P<0.01)$ higher than that of dead cells (4.7\%) and control (3.6\%) treatments, indicating that As(III) oxidation was attributed to fresh cells of Synechocystis but not dead cells or chemical oxidation.

The Percentage of $\mathrm{As}(\mathrm{V})$ in the Medium Was Higher under Elevated $\mathbf{P}$ Concentrations. After exposure of Synechocystis to $10 \mu \mathrm{M}$ As(III) under different P concentrations for 7 days, the percentage of $\mathrm{As}(\mathrm{V})$ to total As in the medium was determined. The percentage of $\mathrm{As}(\mathrm{V})$ increased with increasing $\mathrm{P}$ concentrations $(0-100 \mu \mathrm{M})$ (Figure 1). When the supplied $\mathrm{P}$ concentration was higher than $100 \mu \mathrm{M}$ (including $100 \mu \mathrm{M})$, almost $100 \%$ of total arsenic was As(V) after incubation for 7 days.

Addition of DNP Improved Visible As(III) Oxidation but Not As(V) Reduction in Synechocystis under PLimited Conditions. Under P-limited conditions, the percentage of oxidized $\mathrm{As}(\mathrm{V})$ increased to $23.2 \%$ within $16 \mathrm{~h}$

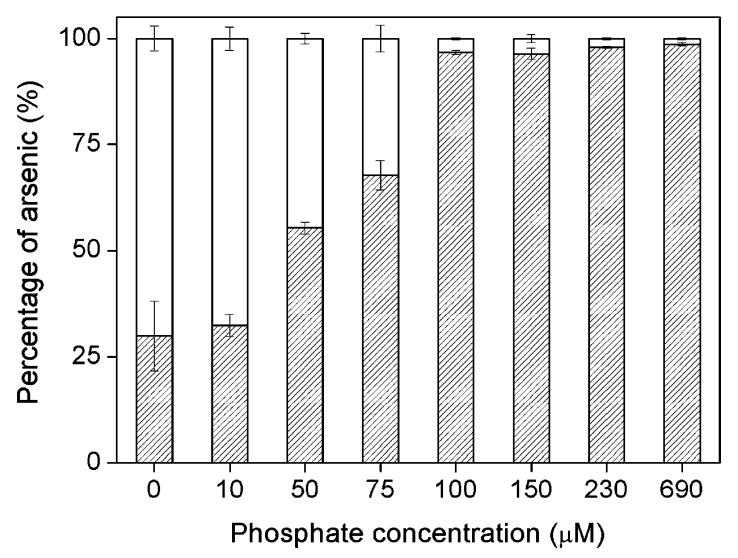

Figure 1. The percentage of As species (hatched bars, As $(\mathrm{V})$; open bars, As(III)) to total As in medium after exposure to $10 \mu \mathrm{M}$ As(III) for 7 days under $0,10,50,75,100,150,230,690 \mu \mathrm{M}$ P. All data are means \pm standard deviation $(n=3)$. and then decreased to $8.7 \%$ at $48 \mathrm{~h}$ in medium with no DNP addition (- P - DNP) (Figure 2). This was possibly due to

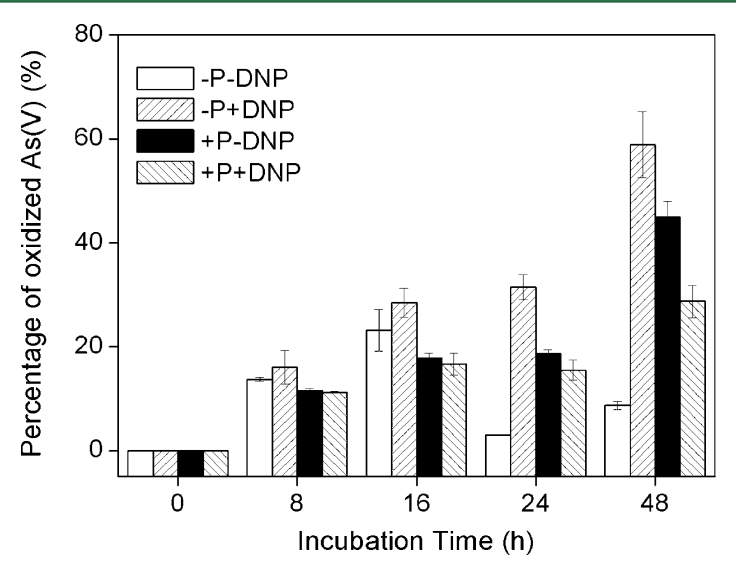

Figure 2. The percentage of oxidized $\mathrm{As}(\mathrm{V})$ to total As in medium incubated with Synechocystis sp. PCC6803 after exposure to $2 \mu \mathrm{M}$ As(III) for $0,8,16,24,48 \mathrm{~h}$ under four treatments (- P - DNP, - P + DNP, + P - DNP, and + P + DNP) during a 48 h cultivation. DNP was supplied at $500 \mu \mathrm{M}$, and $\mathrm{P}$ was supplied at $230 \mu \mathrm{M}$ (the normal $\mathrm{P}$ concentration in BG-11 medium). All data are means \pm standard deviation $(n=3)$.

Synechocystis first oxidized the added As(III) to As(V). Then the uptake of oxidized As (V) by Synechocystis was enhanced by $\mathrm{P}$-limited condition, followed by intracellular As $(\mathrm{V})$ reduction and As(III) efflux (supported by the results in Figures S2, S3, and S4), which contributed to the lower As(V) percentage in the medium, i.e. the decrease of oxidized $\mathrm{As}(\mathrm{V})$ at $48 \mathrm{~h}$. However, under $-\mathrm{P}+\mathrm{DNP}$ treatment, $58.9 \%$ of the $2 \mu \mathrm{M}$ As(III) was oxidized to As(V) within $48 \mathrm{~h}$, higher than the other treatments (- P - DNP (8.7\%), + P - DNP (45.0\%), and $+\mathrm{P}+\mathrm{DNP}(28.8 \%))$. Under P-rich conditions, despite $\mathrm{DNP}$ addition, As(V) percentage showed no significant difference between $+\mathrm{P}-\mathrm{DNP}$ and $+\mathrm{P}+\mathrm{DNP}$ treatments within $24 \mathrm{~h}$, indicating that DNP did not shift the As(III)/ $\mathrm{As}(\mathrm{V})$ ratio in medium. The lower percentage of $\mathrm{As}(\mathrm{V})$ under $+\mathrm{P}+\mathrm{DNP}$ treatment detected on $48 \mathrm{~h}$ might be attributed to poor growth of Synechocystis affected by DNP.

Under P-limited conditions with no DNP addition, the percentage of reduced As(III) increased with incubation time and reached $97.7 \%$ at $24 \mathrm{~h}$ (Figure S2). However, when DNP was added to the P-limited medium ( $-\mathrm{P}+\mathrm{DNP}), \mathrm{As}(\mathrm{V})$ reduction could not be detected during the incubation time. Under P-rich conditions, despite DNP addition, As(V) was always the dominant As species under either $+\mathrm{P}-\mathrm{DNP}$ or $+\mathrm{P}$ + DNP treatments.

DNP and $\mathbf{P}$ Inhibited Intracellular As Accumulation. After exposure to As(III), total As in cells was 4.6, 0.7, 0.6, and $0.1 \mathrm{mM}$ DW, respectively, under - P - DNP, $-\mathrm{P}+\mathrm{DNP},+\mathrm{P}$ $-\mathrm{DNP}$, and $+\mathrm{P}+\mathrm{DNP}$ treatments (Figure S3). When supplied with As $(\mathrm{V})$, total As in cells was 7.9, 1.9, 0.5, and 0.1 mM DW, respectively (Figure S4). Regardless of the species of As exposure, the intracellular As concentrations under + DNP treatments were lower than those under - DNP treatments (+ $\mathrm{P}+\mathrm{DNP}<+\mathrm{P}-\mathrm{DNP},-\mathrm{P}+\mathrm{DNP}<-\mathrm{P}-\mathrm{DNP})$, indicating DNP inhibited As uptake by Synechocystis. Arsenic accumulation in cells was lower under P-rich conditions than under Plimited conditions (+ P + DNP $<-\mathrm{P}+\mathrm{DNP},+\mathrm{P}-\mathrm{DNP}<-$ $\mathrm{P}-\mathrm{DNP})$, suggesting that $\mathrm{P}$ suppressed As uptake, especially 
As $(V)$ uptake. Among all the different treatments, As(V) was always the dominant As species in cells.

Time-Course of Apparent As(III) Oxidation in Medium Differed under P-Rich and -Limited Conditions. Synechocystis was incubated in a medium with $10 \mu \mathrm{M}$ As(III) under either $230 \mu \mathrm{M}$ (P-rich) or $5 \mu \mathrm{M}$ (P-limited) $\mathrm{P}$ conditions, and the concentration of As(III) was monitored over a 10-day period (Figure 3 ). The percentage of $\mathrm{As}(\mathrm{V})$ in the medium

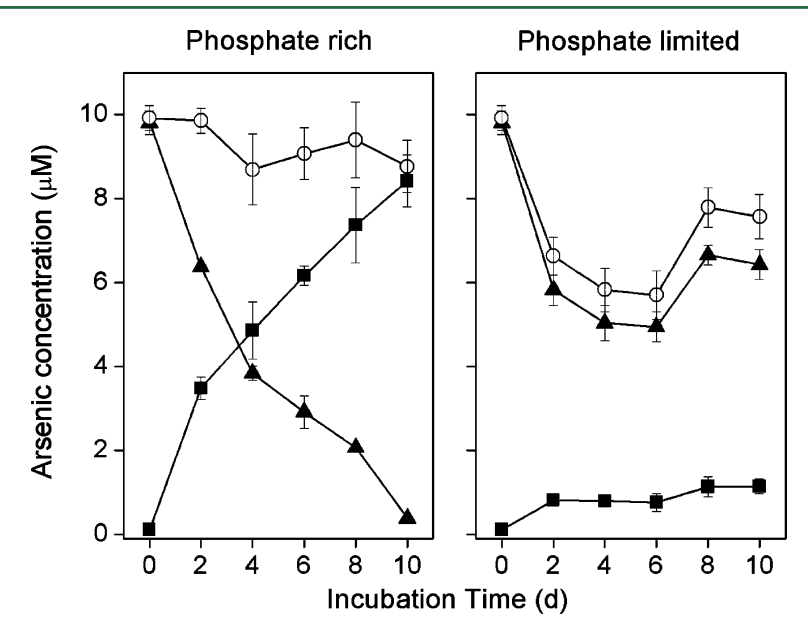

Figure 3. Arsenic species ( $\boldsymbol{\Delta}, \operatorname{As}(\mathrm{III}) ; \mathbf{\square}, \mathrm{As}(\mathrm{V})$; $\mathrm{O}$, sum of different As species) in medium with Synechocystis sp. PCC6803 after exposure to $10 \mu \mathrm{M} \mathrm{As}(\mathrm{III})$ under P-limited $(5 \mu \mathrm{M} \mathrm{P})$ and P-rich $(230 \mu \mathrm{M} \mathrm{P})$ treatments during a $10 \mathrm{~d}$ cultivation. Arsenic species in medium were analyzed on $0,2,4,6,8,10$ days. All data are means \pm standard deviation $(n=3)$.

under P-rich conditions increased more rapidly than that under P-limited conditions. Under P-rich conditions, As(III) concentration decreased with a concomitant increase of As $(\mathrm{V})$ concentration in the medium, from 0.1 to $8.4 \mu \mathrm{M}$, and by day 6, 94\% of the $10 \mu \mathrm{M}$ As(III) added was present as As(V). Under P-limited conditions, As(III) remained to be the predominant As species ( $85-88 \%$ of the total As) during the incubation time, and the $\mathrm{As}(\mathrm{V})$ concentration was stable at $0.8-1.1 \mu \mathrm{M}$ at day $2-10(12-15 \%$ of the total As). The As(III) concentration in the medium decreased from 10 to 4.9 $\mu \mathrm{M}$ after the first 6 days. After 8 days incubation, the As(III) concentration increased to $6.7 \mu \mathrm{M}$. Total As concentration under P-limited conditions decreased from $10 \mu \mathrm{M}$ to $5.7 \mu \mathrm{M}$ within 6 days, which was almost 4 times higher than the decrease $(1.2 \mu \mathrm{M})$ under P-rich conditions, indicating more As uptake by Synechocystis under P-limited conditions.

Time-Course of As Species Accumulated in Synechocystis Was Significantly Different under P-Rich and -Limited Conditions. P limitation had a significant effect on total As concentration as well as on As speciation in cyanobacterial cells (Figure 4). Under P-limited conditions, total As concentration in cells increased rapidly within the first 6 days, reaching up to $7.9 \mathrm{mM} \mathrm{DW}$. This concentration was about 10 times higher than that under P-rich conditions (0.7$0.9 \mathrm{mM}$ DW). During incubation, As speciation was dominated by $\mathrm{As}(\mathrm{V})(82-90 \%$ of the total As) in cyanobacterial cells under P-limited conditions. In contrast, under P-rich conditions, As $(\mathrm{V})$ represented $51-65 \%$ of the total As in cells. Both As(V) and As(III) concentrations in cells showed a decrease after incubation for 6 days under P-limited conditions, and the total As concentration dropped to $5.8 \mathrm{mM} \mathrm{DW}$ at day

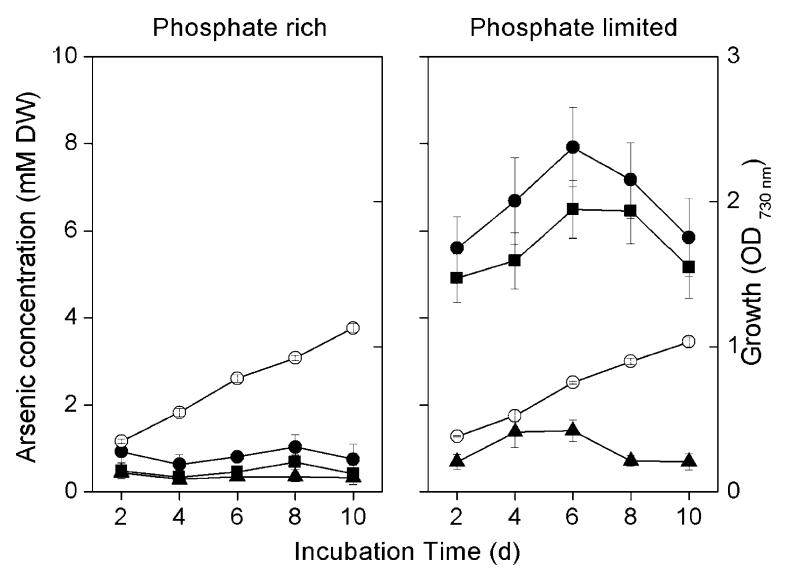

Figure 4. Arsenic species $(\boldsymbol{\Lambda}, \mathrm{As}(\mathrm{III}) ; \mathbf{\square}, \mathrm{As}(\mathrm{V})$; $\boldsymbol{\bullet}$, sum of different As species) in cyanobacterial cells and the growth curve of Synechocystis sp. PCC6803 $\left(\mathrm{O}, \mathrm{OD}_{730 \mathrm{~nm}}\right)$ after exposure to $10 \mu \mathrm{M}$ As(III) under P-limited $(5 \mu \mathrm{M} \mathrm{P})$ and P-rich $(230 \mu \mathrm{M} \mathrm{P})$ treatments during a $10 \mathrm{~d}$ cultivation. Arsenic species in Synechocystis were analyzed on $2,4,6,8,10$ days. All data are means \pm standard deviation $(n=3)$.

10, indicating that Synechocystis might efflux part of the As(V) and As(III) from cells to the medium, as a possible As detoxification mechanism in cyanobacteria. ${ }^{5}$ During the incubation time $(10 \mathrm{~d}), \mathrm{OD}_{730 \mathrm{~nm}}$ of Synechocystis under 230 $\mu \mathrm{M}$ and $5 \mu \mathrm{M}$ P conditions showed no significant difference (Figure 4).

Transcription Analysis of ars $C$ under Different $P$ and As(III) Levels. The expression of gene involved in $\mathrm{As}(\mathrm{V})$ reduction $(\operatorname{ars} C)$ under different $\mathrm{P}$ and $\mathrm{As}(\mathrm{III})$ levels $(+\mathrm{P}+$ As(III), + P - As(III), - P + As(III), - P - As(III)) was analyzed using qRT-PCR (Figure 5). With As(III) addition, the

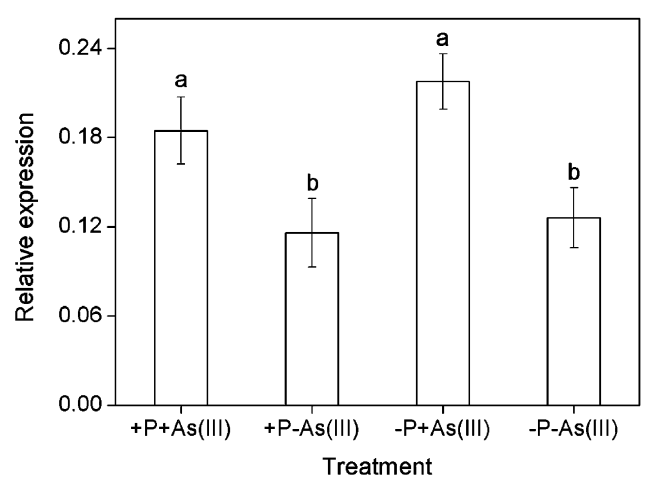

Figure 5. qPCR analysis to investigate ars $C$ transcriptions. Total RNA was isolated from Synechocystis sp. PCC6803 under four treatments (+ $\mathrm{P}+\mathrm{As}(\mathrm{III}),+\mathrm{P}-\mathrm{As}(\mathrm{III}),-\mathrm{P}+\mathrm{As}(\mathrm{III}),-\mathrm{P}-\mathrm{As}(\mathrm{III}))$ after incubation for 7 days. Arsenite was supplied at $10 \mu \mathrm{M}$, and $\mathrm{P}$ was supplied at $230 \mu \mathrm{M}$. All data are means \pm standard deviation $(n=3)$. The transcription level of ars $C$ under + As(III) treatments were significantly $(P<0.01)$ different from treatments of $-\mathrm{As}(\mathrm{III})$.

two $\mathrm{P}$ levels did not significantly influence $\operatorname{ars} C$ expression in Synechocystis. However, regardless of $\mathrm{P}$ levels, the addition of As(III) significantly $(P<0.01)$ enhanced ars $C$ transcription levels in Synechocystis.

\section{DISCUSSION}

Our results indicated that As(III) oxidation was mediated by fresh cyanobacterial cells, because neither dead cells (Figure S1) nor cyanobacterial excretion had any effect on it, 5 and 
As(III) oxidation by Synechocystis was much more rapid than chemical oxidation (Figure S1). As an uncoupler of oxidative phosphorylation, DNP can cause dissipation of the proton motive force across the membranes and thus inhibits As uptake by Synechocystis but should not change As redox processes. Based on the fact that DNP had no significant effect on $24 \mathrm{~h}$ As(III) oxidation under $+\mathrm{P}-\mathrm{DNP}$ and $+\mathrm{P}+\mathrm{DNP}$ treatments (Figure 2), we therefore suggest that As(III) oxidation in Synechocystis is likely a surface oxidation process (either in the periplasm or near the outer membrane) rather than intracellular As(III) oxidation following As(III) uptake. As(III) oxidation in many microorganisms, such as Agrobacterium tumefaciens $5 \mathrm{~A},{ }^{28}$ Herminiimonas arsenicoxydans ULPAs $1,{ }^{29}$ Rhizobium sp. NT$26,^{30}$ and Thiomonas sp. 3As, ${ }^{31}$ has been reported to be mediated by the respiratory As(III) oxidase which is considered to be a periplasmic protein (found outside the inner cell membrane but associated with it). ${ }^{32,33}$ However, a related As(III) oxidase in Synechocystis has yet to be identified and perhaps does not exist. Of course, other, unrelated enzymes might be responsible for As(III) oxidation in Synechocystis and perhaps other cyanobacteria.

Phosphate as an important environmental factor could influence $\mathrm{As}(\mathrm{V})$ uptake and reduction in microorganisms. $^{15,16,34,35}$ Our study indicated that the presence of $\mathrm{P}$ could inhibit intracellular As $(\mathrm{V})$ reduction (Figure S2) by decreasing As(V) uptake in Synechocystis (Figure S4). The impeding of $\mathrm{As}(\mathrm{V})$ uptake by $\mathrm{P}$ might via $\mathrm{P}$ transport systems or by competitively binding to the active site of ArsC. ${ }^{15,35}$ Our results also revealed that a higher $\mathrm{P}$ concentration resulted in a higher As(V) percentage in the medium as a result of As(III) oxidation by Synechocystis (Figure 1). The difference in As(III) oxidation under P-limited and P-rich conditions more likely resulted from a $\mathrm{P}$ effect rather than the difference in growth of Synechocystis, since $\mathrm{OD}_{730 \mathrm{~nm}}$ of Synechocystis in the two media showed no difference during the incubation period (Figure 4). We further suggest that the lower $\mathrm{As}(\mathrm{V})$ percentage in the medium, i.e. lower As(III) oxidation, under P-limited conditions is not due to the direct inhibition of low $\mathrm{P}$ on As(III) oxidation. The possible pathway of this influence is as follows: under P-limited conditions, uptake of oxidized As(V) was enhanced; therefore, intracellular $\mathrm{As}(\mathrm{V})$ reduction was increased and then followed by As(III) efflux. This is supported by the results from the $-\mathrm{P}+\mathrm{DNP}$ treatment, in which DNP inhibited As uptake and reduced intracellular As(V) reduction in Synechocystis (Figures S2, S3, and S4), thus leading to a higher percentage of As(V), i.e. higher As(III) oxidation in the medium under P-limited conditions (Figure 2). Under P-rich conditions, the presence of $\mathrm{P}$ inhibited intracellular $\mathrm{As}(\mathrm{V})$ reduction and subsequent As(III) efflux by impeding the uptake of oxidized $\mathrm{As}(\mathrm{V})$ from the medium and therefore contributing to the higher $\mathrm{As}(\mathrm{V})$ percentage in the medium, i.e. higher net As(III) oxidation (Figures 2 and 3). Considering Synechocystis has been recognized as a typical freshwater cyanobacterium, we believe that $\mathrm{P}$ will influence As redox processes in other cyanobacteria as well.

The higher percentage of As(III) in the medium under Plimited conditions was likely due to improved As (V) uptake, and subsequent efflux of intracellular reduced As(III) in a dynamic cycle of an As redox process under P-limited conditions. We propose the following model to depict the predominance of As(III) under P-limited conditions. First, As(III) was oxidized to As(V) by surface oxidation as discussed above. Second, more As(V) was taken up into cells under P- limited condition (Figure 4) through the upregulated $\mathrm{P}$ transporter system, ${ }^{12}$ resulting in a decreased As(V) concentration in the medium (Figure 3). The intracellular As(V) was then reduced to As(III) and subsequently effluxed out of the cells into the medium for detoxification ${ }^{13,14}$ and thus resulted in the higher As(III) concentration in the medium (Figure 3). Furthermore, As(III) effluxed to the medium may once more be oxidized by Synechocystis and generate a dynamic cycle of As redox processes. Intracellular As(V) reduction and As(III) efflux were improved by As(III) addition, as indicated by a significantly higher expression of arsC under + As(III) treatment (Figure 5), and led to an As redox cycle in Synechocystis. The expression of acr3 (encoding the As(III) efflux pump) could be similar to ars $C$, since it is in the same operon in Synechocystis. ${ }^{22,23}$ Phosphate levels did not influence arsC expression (Figure 5), which had also been demonstrated in Agrobacterium tumefaciens str. 5B and Shewanella sp. Strain ANA - 3. ${ }^{15,36}$

Our results also revealed that As uptake in Synechocystis was an active process, because DNP significantly inhibited both $\mathrm{As}(\mathrm{III})$ and $\mathrm{As}(\mathrm{V})$ accumulation in cyanobacterial cells (Figures S3 and S4). As(III) uptake has been generally accepted as an energy-dependent process, mainly via aquaglyceroporins (transport of water, glycerol, and other small uncharged molecules) in bacteria. ${ }^{37} \mathrm{As}(\mathrm{V})$ uptake can be catalyzed by two $\mathrm{P}$ transporters in E. coli, the P-specific transport (Pst) system and P-inorganic transport (Pit) system. $^{38}$ In the cyanobacteria Microcystis aeruginosa, Guo et al. have proposed that $\mathrm{As}(\mathrm{V})$ absorption was through the Pit system under 0,1 , and $10 \mu \mathrm{M} \mathrm{P}$, while the Pst system was the major uptake pathway under $175 \mu \mathrm{M} \mathrm{P} .^{12}$ For Synechocystis, higher As(V) accumulation in cells under Plimited conditions (Figure 4) might be attributed to As(V) absorption through the Pit system which has lower affinity to P.

In conclusion, our results demonstrated that in the presence of cyanobacterium-Synechocystis, arsenic redox dynamics was influenced by P levels. As(III) oxidation by Synechocystis appeared to be more effective with increased P levels, indicating that $\mathrm{P}$ concentrations should be taken into consideration when predicting the effect of biological As(III) oxidation, such as under algal bloom conditions. Since As(V) is less toxic to humans and much easier to remove by conventional treatments, such as coagulation, coprecipitation, and adsorption process, ${ }^{39-41}$ there is a possibility of increasing $\mathrm{As}(\mathrm{V})$ in the environment by cyanobacterial oxidation through regulating $\mathrm{P}$ concentrations and thus facilitate As removal from solution. Moreover, considering Synechocystis is the model cyanobacterium, and widely spread in some $\mathrm{P}$ and arsenic coexisting environments, such as a eutrophic aquatic environment as well as artificial wetland-paddy fields, ${ }^{17,18}$ we reasonably speculate the biogeochemical coupling of arsenic and phosphorus exists in these aquatic and wetland environments.

\section{ASSOCIATED CONTENT}

\section{S Supporting Information}

Sequences of primers used for real-time quantitative reversetranscription polymerase chain reaction (qRT-PCR); the results of As(III) oxidation by Synechocystis, dead cells, and control treatment; the results of $\mathrm{As}(\mathrm{V})$ reduction by Synechocystis under - P - DNP, - P + DNP, + P - DNP, and $+\mathrm{P}+\mathrm{DNP}$ treatments; As species in cyanobacterial cells under - P - DNP, - P + DNP, + P - DNP, and + P + DNP treatments. This material is available free of charge via the Internet at http://pubs.acs.org. 


\section{AUTHOR INFORMATION}

\section{Corresponding Author}

*E-mail: ygzhu@rcees.ac.cn.

\section{Notes}

The authors declare no competing financial interest.

\section{ACKNOWLEDGMENTS}

This study was financially supported by Natural Science Foundation of China (No. 21077100). We would like to thank to Guoxin Sun and Guilan Duan in Research Center for Eco-Environmental Sciences, Chinese Academy of Sciences for their constructive suggestions during experiments. We also thank Dr. Patrick O'Connor at the University of Adelaide for constructive suggestions during revision.

\section{REFERENCES}

(1) Bhattacharya, P.; Welch, A. H.; Stollenwerk, K. G.; McLaughlin, M. J.; Bundschuh, J.; Panaullah, G. Arsenic in the environment: biology and chemistry. Sci. Total Environ. 2007, 379 (2-3), 109-120.

(2) Wang, S.; Mulligan, C. N. Occurrence of arsenic contamination in Canada: sources, behavior and distribution. Sci. Total Environ. 2006, 366 (2-3), 701-721.

(3) Oremland, R. S.; Stolz, J. F. The ecology of arsenic. Science 2003, 300 (5621), 939-944.

(4) Vithanage, M.; Dabrowska, B. B.; Mukherjee, A. B.; Sandhi, A.; Bhattacharya, P. Arsenic uptake by plants and possible phytoremediation applications: a brief overview. Environ. Chem. Lett. 2012, 10 (3), 217-224.

(5) Yin, X. X.; Wang, L. H.; Bai, R.; Huang, H.; Sun, G. X. Accumulation and transformation of arsenic in the blue-green alga Synechocysis sp. PCC6803. Water, Air, Soil Pollut. 2011, 223 (3), 11831190.

(6) Yin, X. X; Wang, L. H.; Duan, G. L.; Sun, G. X. Characterization of arsenate transformation and identification of arsenate reductase in a green alga Chlamydomonas reinhardtii. J. Environ. Sci. 2011, 23 (7), 1186-1193.

(7) Pawlik-Skowrońska, B.; Pirszel, J.; Kalinowska, R.; Skowroński, T. Arsenic availability, toxicity and direct role of GSH and phytochelatins in As detoxification in the green alga Stichococcus bacillaris. Aquat. Toxicol. 2004, 70 (3), 201-212.

(8) Šlejkovec, Z.; Kápolna, E.; Ipolyi, I.; Elteren, J. T. Arsenosugars and other arsenic compounds in littoral zone algae from the adriatic sea. Chemosphere 2006, 63 (7), 1098-1105.

(9) Ye, J.; Rensing, C.; Rosen, B. P.; Zhu, Y. G. Arsenic biomethylation by photosynthetic organisms. Trends Plant. Sci. 2012, 17 (3), 155-162.

(10) Zhao, F. J.; Ma, J.; Meharg, A.; McGrath, S. Arsenic uptake and metabolism in plants. New Phytol. 2009, 181 (4), 777-794.

(11) Levy, J. L.; Stauber, J. L.; Adams, M. S.; Maher, W. A.; Kirby, J. K.; Jolley, D. F. Toxicity, biotransformation, and mode of action of arsenic in two freshwater microalgae (Chlorella sp. and Monoraphidium arcuatum). Environ. Toxicol. Chem. 2005, 24 (10), 2630-2639.

(12) Guo, P.; Gong, Y.; Wang, C.; Liu, X.; Liu, J. Arsenic speciation and effect of arsenate inhibition in a Microcystis aeruginosa culture medium under different $\mathrm{P}$ regimes. Environ. Toxicol. Chem. 2011, 30 (8), 1754-1759.

(13) Rosen, B. P. Biochemistry of arsenic detoxification. FEBS Lett. 2002, 529 (1), 86-92.

(14) Cervantes, C.; Ramirez, J. L.; Silver, S. Resistance to arsenic compounds in microorganisms. FEMS Microbiol. Rev. 1994, 15 (4), $355-367$.

(15) Slaughter, D. C.; Macur, R. E.; Inskeep, W. P. Inhibition of microbial arsenate reduction by P. Microbiol. Res. 2012, 167 (3), 151156.

(16) Kang, Y. S.; Heinemann, J.; Bothner, B.; Rensing, C.; McDermott, T. R. Integrated co-regulation of bacterial arsenic and phosphorus metabolisms. Environ. Microbiol. 2012, 14 (12), 30973109.

(17) Song, T.; Mårtensson, L.; Eriksson, T.; Zheng, W.; Rasmussen, $\mathrm{U}$. Biodiversity and seasonal variation of the cyanobacterial assemblage in a rice paddy field in Fujian, China. FEMS Microbiol. Ecol. 2005, 54 (1), $131-140$.

(18) Pisciotta, J. M.; Zou, Y.; Baskakov, I. V. Light-dependent electrogenic activity of cyanobacteria. PLoS One 2010, 5 (5), 1-10.

(19) Schindler, D. W. Recent advances in the understanding and management of eutrophication. Limnol. Oceanogr. 2006, 51 (1), 356363.

(20) Bianchi, T. S.; Engelhaupt, E.; Westman, P.; Andren, T.; Rolff, C.; Elmgren, R. Cyanobacterial blooms in the Baltic Sea: Natural or human-induced. Limnol. Oceanogr. 2000, 45 (3), 716-726.

(21) Dokulil, M. T.; Teubner, K. Cyanobacterial dominance in lakes. Hydrobiologia 2000, 438 (1), 1-12.

(22) López-Maury, L.; Florencio, F. J.; Reyes, J. C. Arsenic sensing and resistance system in the cyanobacterium Synechocystis sp. strain PCC 6803. J. Bacteriol. 2003, 185 (18), 5363-5371.

(23) López-Maury, L.; Sánchez-Riego, A. M.; Reyes, J. C.; Florencio, F. J. The glutathione/glutaredoxin system is essential for arsenate reduction in Synechocystis sp. strain PCC 6803. J. Bacteriol. 2009, 191 (11), 3534-3543.

(24) Rippka, R.; Deruelles, J.; Waterbury, J. B.; Herdman, M.; Stanier, R. Y. Generic assignments, strain histories and properties of pure cultures of cyanobacteria. J. Gen. Microbiol. 1979, 111 (1), 1-61.

(25) Osborn, M. J.; McLellan, W. L., Jr.; Horecker, B. L. Galactose transport in Escherichia coli. J. Biol. Chem. 1961, 236 (10), 25852589.

(26) Zhu, Y. G.; Sun, G. X.; Lei, M.; Teng, M.; Liu, Y. X.; Chen, N. C.; Wang, L. H.; Carey, A.; Deacon, C.; Raab, A. High percentage inorganic arsenic content of mining impacted and nonimpacted Chinese rice. Environ. Sci. Technol. 2008, 42 (13), 5008-5013.

(27) Pfaffl, M. W. A new mathematical model for relative quantification in real-time RT-PCR. Nucleic Acids. Res. 2001, 29 (9), 2002-2007.

(28) Kashyap, D. R.; Botero, L. M.; Franck, W. L.; Hassett, D. J.; McDermott, T. R. Complex regulation of arsenite oxidation in Agrobacterium tumefaciens. J. Bacteriol. 2006, 188 (3), 1081-1088.

(29) Muller, D.; Médigue, C.; Koechler, S.; Barbe, V.; Barakat, M.; Talla, E.; Bonnefoy, V.; Krin, E.; Arsène-Ploetze, F.; Carapito, C. A tale of two oxidation states: bacterial colonization of arsenic-rich environments. PLoS Genet. 2007, 3 (4), 518-530.

(30) Santini, J. M.; Sly, L. I.; Schnagl, R. D.; Macy, J. M. A new chemolithoautotrophic arsenite-oxidizing bacterium isolated from a gold mine: phylogenetic, physiological, and preliminary biochemical studies. Appl. Environ. Microbiol. 2000, 66 (1), 92-97.

(31) Duquesne, K.; Lieutaud, A.; Ratouchniak, J.; Muller, D.; Lett, M. C.; Bonnefoy, V. Arsenite oxidation by a chemoautotrophic moderately acidophilic Thiomonas sp.: from the strain isolation to the gene study. Environ. Microbiol. 2008, 10 (1), 228-237.

(32) Silver, S.; Phung, L. T. Genes and enzymes involved in bacterial oxidation and reduction of inorganic arsenic. Appl. Environ. Microbiol. 2005, 71 (2), 599-608.

(33) Silver, S.; Phung, L. T. A bacterial view of the periodic table: genes and proteins for toxic inorganic ions. J. Ind. Microbiol. Biot. 2005, 32 (11), 587-605.

(34) Markley, C. T.; Herbert, B. E. Modeling P influence on arsenate reduction kinetics by a freshwater cyanobacterium. Environ. Model. Assess. 2010, 15 (5), 361-368.

(35) Wang, N. X.; Li, Y.; Deng, X. H.; Miao, A. J.; Ji, R.; Yang, L. Y. Toxicity and bioaccumulation kinetics of arsenate in two freshwater green algae under different P regimes. Water Res. 2013, 47 (7), $2497-$ 2506.

(36) Saltikov, C. W.; Wildman, R. A.; Newman, D. K. Expression dynamics of arsenic respiration and detoxification in Shewanella sp. strain ANA-3. J. Bacteriol. 2005, 187 (21), 7390-7396.

(37) Slyemi, D.; Bonnefoy, V. How prokaryotes deal with arsenic. Environ. Microbiol. Rep. 2012, 4 (6), 571-586. 
(38) Willsky, G. R.; Malamy, M. H. Characterization of two genetically separable inorganic $\mathrm{P}$ transport systems in Escherichia coli. J. Bacteriol. 1980, 144 (1), 356-365.

(39) Ito, A.; Miura, J. I.; Ishikawa, N.; Umita, T. Biological oxidation of arsenite in synthetic groundwater using immobilised bacteria. Water Res. 2012, 46 (15), 4825-4831.

(40) Katsoyiannis, I. A.; Zouboulis, A. I. Removal of arsenic from contaminated water sources by sorption onto iron-oxide-coated polymeric materials. Water Res. 2002, 36 (20), 5141-5155.

(41) Kartinen, E. O.; Martin, C. J. An overview of arsenic removal processes. Desalination 1995, 103 (1), 79-88. 